УДК 340.121

https://doi.org/10.34142/23121661.2021.33.15

orcid. org/0000-0002-2351-4288

(C) Кошарновская С.Л., 2021

\title{
С.Л. КОШАРНОВСЬКА
}

\section{ПРАВОВІ ФОРМИ ЗДІЙСНЕННЯ ФУНКЦІЙ ДЕРЖАВИ: ПОНЯТТЯ ТА ВИДИ}

\section{S. KOSHARNOVS'KA}

\section{LEGAL FORMS OF IMPLEMENTATION OF STATE FUNCTIONS: THE CONCEPT AND TYPES}

Анотація: Мета наукової статті полягає в окресленні окремих проблем у визначенні поняття правових форм реалізації соціальної функції держави, оскільки таку діяльність виконують окремі уповноважені державою органи та посадові особи та винятково в спосіб, установлений законом. Зміст державної влади розкривається в іiї функціях, компетенції суб'єктів, формах і методах реалізації їхніх повноважень. У статті запропоновано визначення правових форм здійснення функцій державної влади, зокрема проаналізовано інші форми реалізації соціальної функції, серед яких вагоме місце посідає контрольно-наглядова форма, що передбачає здійснення контролю за діяльністю державних органів у соціальній сфері не тільки парламентом, урядом та іншими органами, що належать до вертикалі державної виконавчої влади, а й органами, що чинять правосуддя.

Ключові слова: соціальна функція держави, види правових форм реалізації державних функцій, правові форми здійснення соціальної функції.

Аннотация. Цель научной статьи заключается в выявлении отдельных проблем в определении понятия правовых форм реализации социальной функции государства, поскольку такую деятельность выполняют отдельные уполномоченные государством органы и должностные лица и исключительно в установленном законом порядке. Содержание государственной власти раскрывается в ее функциях, компетенции субъектов, формах и методах реализации их полномочий. В статье предложено определение правовых форм осуществления функций государственной власти, кроме того, проанализированы другие формы реализации социальной функции, среди которых весомое место занимает контрольнонаблюдательная форма, которая предусматривает осуществление контроля за деятельностью государственных органов в социальной сфере не только парламентом, правительством и другими органами, которые составляют вертикаль государственной исполнительной власти, но и органами, вершащими правосудие.

Ключевые слова: социальная функция государства, виды правовых форм реализации государственных функций, правовые формы осуществления социальной функции. 
Abstract. The purpose of the scientific article is to identify certain problems in defining the concept of legal forms of implementation of the social function of the state, as such activities are performed by separate bodies and officials authorized by the state and only in the manner prescribed by law. The content of state power is revealed in its functions, competences of subjects, forms and methods of realization of their powers. The article proposes the definition of legal forms of state power, in addition, analyzes other forms of social function, among which an important place is the control and supervision form, which provides for control over the activities of state bodies in the social sphere not only parliament, government and other bodies. are part of the vertical of state executive power, but also the bodies that administer justice.

Key words: social function of the state, types of legal forms of realization of state functions, legal forms of realization of social function.

Постановка проблеми. Держава реалізує свою владу через діяльність органів, які згідно з наданим повноваженням створюють, реалізують і охороняють правові норми для врегулювання суспільних відносин шляхом правотворення, правозастосування і правоохорони. Розмежування сфери впливу зазначених форм і запобігання несанкціонованій підміні понять і викликало необхідність цього дослідження.

Аналіз останніх досліджень. Питання реалізації державних функцій привертало увагу багатьох науковців, серед яких варто згадати Р.3. Лівшица, О.В. Зайчука, Н.М. Оніщенка, А.Б. Венгерова, В.С. Чиркіна, В.С. Афанасьєва, О.Г. Братко, В.Н. Бутиліна, А.Ф. Черданцева, М.В. Цвіка, О.В. Петришина та ін.

Проблема визначення сутності правових форм реалізації державних функцій формування їхнього поняття та виокремлення властивостей привертала увагу багатьох сучасних вітчизняних науковців. Так, Р.Я. Шай [1] вважає за необхідне визначити чітке формулювання принципів i форм реалізації функцій держави і наголошує, що саме вони не лише забезпечують єдність та системність функцій, а й установлюють засоби їхнього зовнішнього прояву та реалізації. В. Сирих пропонує під правовою формою реалізації функцій держави розуміти «весь механізм правового регулювання» [2].

C.M. Мельничук [3], досліджуючи правоохоронну діяльність як форму здійснення функцій держави, наголошує на визначенні змісту термінів «охорона» i «захист», i як наслідок установлює співвідношення понять «правоохоронна діяльність» і «правозахисна діяльність» [3].

T.B. Дружиніна-Сендецька [4] вважає, що інтерпретаційно-правову форму реалізації функцій держави здійснюють і судові органи, що судова практика, зважаючи на результати діяльності судів, у повному обсязі є джерелом права, а суд - творцем права, поряд із правотворчою, що реалізується єдиним законодавчим органом нашої держави - Парламентом. 
Отже, думки вчених щодо правових форм діяльності органів держави мають різноманітний характер. Проблема функцій української держави на будь-якому етапі іiі розвитку є до того ж однією з найважливіших та дискусійних у теорії держави та права, а форми їхньої реалізації потребують додаткового дослідження.

Формулювання мети статті (постановка завдання). Мета статті полягає в з'ясуванні природи правових форм здійснення функцій держави, формулювання на цій основі визначення поняття та розмежування форм реалізації, оскільки в них виявляється соціальне призначення держави в суспільстві.

Виклад основного матеріалу. Проголошення України соціальною державою потребувало не лише формального самовизначення іiі соціальної спрямованості, але й розроблення стратегії соціальної політики держави як основного напряму діяльності такої держави. Упродовж усього часу розбудови України як соціальної правової держави потребують вдосконалення чинні в державі форми, методи та засоби реалізації державних функцій, та, мабуть, один із найважливіших напрямів діяльності - державна підтримка тих верств населення, що потребують соціальної захищеності саме від держави.

Державна підтримка полягає в реалізації державних функцій $\mathrm{i}$, зокрема, соціальної, через основні правові форми, пов'язані зі створенням, реалізацією та охороною правових норм. Ці функції передбачають правотворчу, правозастосовну (правовиконавчу) і правоохоронну (правозабезпечувальну) діяльність. Крім того, особливої уваги в сучасних умовах набувають такі форми, як контрольно-наглядова та правосудна, що забезпечують законність реалізації правотворчої та правозастосовної форм реалізації соціальної функції держави [3].

У юридичній науці прийнято розрізняти правові й неправові форми реалізації функцій держави. У правових формах відтворюються зв'язок держави й права, обов'язок держави діяти на основі права й у межах закону. Правові ж форми є діяльністю, пов'язаною зі здійсненням юридично значущих дій у визначеному законом порядку. Крім того, ці форми відображають те, у який спосіб працюють державні органи та їхні посадові особи, які юридично значущі дії вони здійснюють.

Оскільки державна влада відрізняється від інших видів публічної влади сукупністю владних повноважень, що здійснюються на законодавчому рівні від імені суспільства публічними органами, а право є універсальною соціальнонормативною системою, норми якої можуть бути матеріалізовані лише через апарат держави, то можна зробити висновок, що саме державі належить провідна роль у реалізації відповідних функцій через правові форми.

Правова форма здійснення функцій державної влади - це встановлений (передбачений) законом або іншою формою права (підзаконним нормативним 
актом, прецедентом, правовим звичаєм тощо) спосіб вираження (доведення до суб'єктів виконання) та реалізації (забезпечення виконання) волі центральної влади держави, призначений для досягнення конкретно-визначених державних функцій і відповідних їм завдань у передбачений законом спосіб.

Зовнішнє вираження здійснення державної влади залежить від функції, що реалізується через конкретне волевиявлення держави, від джерела державного волевиявлення та державного органу, уповноваженого законом на здійснення окремо взятої державної функції.

Логічна конструкція наведеного визначення припускає, що форма здійснення державної влади як зовнішнє відображення іiі централізуючої владної волі залежить від конкретного іï джерела і визначається його функціональним призначенням, компетенцією та регламентом реалізації функціональних повноважень.

Іншими словами, форми діяльності державної влади можна визначити як нормативно-типізовані прояви дій відповідних компетентних органів із реалізації функцій держави.

У загальнотеоретичному тлумаченні категорія «форма» органічно пов’язана 3 іншою категорією такого самого плану - категорією «зміст». У цьому аспекті під формою розуміється те чи інше структуроване вираження змісту. Форма не просто виражає зміст, а виражає його структуровано, тобто у вигляді систематизованих та ієрархізовано-субординованих правових норм. Щодо державної влади така форма є проявом іiі державно-правового змісту у вигляді централізуючої волі, яка знайшла прояв у нормативно-правових типізаціях.

Зміст державної влади розкривається в пї функціях, компетенції суб’ єктів, формах і методах реалізації. Діючи в межах свого статусу та своєї компетенції, кожна гілка державної влади на своєму рівні користується в цьому випадку різними методами (засобами), серед яких перебувають: економічні методи (з використанням матеріальної зацікавленості), організаційні методи (з використанням кадрової справи), моральні методи (з використанням моральних заходів заохочення), правові методи (постанови, накази, розпорядження), технічні (організаційна техніка) та ін.

В. Чиркін у зв'язку із цим справедливо зауважує, що методи управління переходять у правову форму і «співвідношення методів управління та відповідних форм полягає в тому, що якщо метод відображає зміст управлінської діяльності, то форма є способом вираження цього змісту» [9].

У процесі визначення поняття правових форм реалізації державних функцій у науковій літературі не наведено істотних відмінностей у теоретичних позиціях різних авторів. Усі розглядають їх як діяльність, пов’язану 3 виданням правових актів, що мають юридичні наслідки. 
Водночас більшість авторів виокремлюють правотворчу діяльність, оперативно-виконавчу діяльність, правоохоронну діяльність. Деякі автори до цього переліку додають ще нагляд і контроль за виконанням права. Отже, значна кількість авторів сходиться на тому, що правові форми пов'язані зі створенням, реалізацією та охороною правових норм і передбачають правотворчу, правозастосовну (правовиконавчу) i правоохоронну (правозабезпечувальну) діяльність [11].

Для ефективного впливу на різного роду суспільні відносини державою має бути встановлений певний механізм, чітко виражений в нормативноправових актах. Тому процес впливу держави на ці відносини, як правило, починається 3 видання правових актів, якими встановлюються відповідний порядок і процедура діяльності органів державної влади.

Оскільки правотворча діяльність держави значною мірою спрямована на вирішення державних завдань, функцій та цілей, правотворчість стає однією 3 основних форм, за допомогою яких реалізуються державні функції. Однак, як уже зазначалося, цей вид діяльності, будучи засобом, способом, тобто функцієюоперацією для держави загалом, у свою чергу стає основною функцією для тих державних органів (насамперед законодавчих), які покликані здійснювати правотворчість.

Іншими словами, правотворчість є однією з форм здійснення державної влади. Отже, виходячи із запропонованої вище класифікації правових форм реалізації державних функцій, можна вивести таке визначення способів реалізації опосередкованої форми здійснення державної влади.

Під формами здійснення державної влади розуміється діяльність державних органів, пов'язана із створенням, реалізацією та охороною правових норм за допомогою правотворчості, правозастосування та правоохорони (правозабезпечення), що має юридичні наслідки.

Правотворчість як спосіб реалізації опосередкованої форми здійснення державної влади є процесом створення або санкціонування відповідних нормативних актів, зокрема з метою зміни або скасування чинних юридичних норм. Без цієї форми реалізація функцій держави є практично неможливою [12].

Особливе місце в правотворчості держави посідає законодавча діяльність вищих органів державної влади. На основі та на виконання нормативних актів, які мають вищу юридичну силу - законів, складається як правотворча, так i правозастосовна діяльність усіх інших органів держави, а також уповноважених на здійснення цієї діяльності інших організацій.

Зміни, що відбуваються в Україні, не могли не позначитися на правотворчих процесах. Основне завдання правотворчості полягає в створенні, оновленні та вдосконаленні законодавства. У ході іiі вирішення приймаються нові норми, змінюються вже наявні, скасовуються застарілі. 
Державна влада не тільки організовує та встановлює порядок регулювання суспільних відносин через правотворчу форму, вона також практично впливає на ці відносини, що відбувається найчастіше в правозастосовній формі реалізації державних функцій відповідно до правових актів, які видаються державою.

Правозастосовний (або правовиконавчий) спосіб реалізації опосередкованої форми здійснення державної влади є діяльністю органів держави, спрямованою на виконання законів і підзаконних нормативних актів шляхом видання правозастосовних актів. У правозастосуванні здійснюється насамперед оперативна, владна, виконавчо-розпорядча робота уповноважених посадових осіб державних органів, що пов'язана з вирішенням управлінських питань шляхом видання актів застосування правових норм, які є підставою для виникнення, зміни або припинення правовідносин. За допомогою цієї діяльності реалізуються відносини між органами держави, громадськими організаціями та громадянами, їхні взаємні права та обов'язки.

Держава зобов'язана охороняти норми права від порушень, забезпечувати режим законності та правопорядку. У цьому полягає третій правовий спосіб реалізації опосередкованої форми здійснення державної влади - правоохоронний, або правозабезпечувальний.

В юридичній літературі частіше за все йдеться про правоохоронну діяльність. У іiї здійсненні так чи інакше беруть участь усі органи державної влади, адміністрація підприємств, установ тощо, а також і деякі недержавні організації.

Кожен державний орган має певну компетенцію та не має права ухилятися від виконання своїх обов'язків або виходити за межі наданих йому повноважень. Для вирішення цих завдань органам державної влади надаються державно-владні повноваженнями, обсяг яких визначається цілями й завданнями державного управління в тих чи інших сферах суспільного життя [10].

Правоохорона як спосіб реалізації опосередкованої форми здійснення державної влади - це діяльність, реалізована «за допомогою владної оперативної роботи державних органів з охорони норм права від порушень, захисту прав і свобод громадян та їхніх об'єднань, забезпечення виконання покладених на них юридичних обов'язків, охорони законності й правопорядку». Вона передбачає прийняття заходів: щодо попередження правопорушень, розслідування всіх обставин справи і з'ясування істини в кожному випадку правопорушення, вирішення в установленому законом порядку конкретних справ про порушення правових норм, а також можливих правових колізій та суперечок, застосування правових санкцій щодо правопорушників та забезпечення реалізації їхньої юридичної відповідальності, і також відновлення порушеного права. Основну частину цієї діяльності здійснюють правоохоронні органи. Коло органів, які $є$ 
правоохоронними, не є статичними, на певних етапах суспільного розвитку воно має тенденції до звуження або до розширення [12].

У правоохоронній діяльності органів державної влади існує державний примус, що застосовується до тих, хто добровільно не виконує приписи та вимоги норми права. Разом із тим, важливого значення в ній набувають профілактика правопорушень, виховання і переконання.

Метою правоохорони є контроль за відповідністю діяльності суб’єктів права юридичним розпорядженням, іiі правомірністю, а в разі виявлення правопорушення - прийняття відповідних заходів для відновлення порушеного права, застосування заходів державного примусу до правопорушників та забезпечення виконання заходів покарання (стягнення).

Окремими правовими формами реалізації соціальної функції є установча, контрольно-наглядова, інтерпретаційно-правова та правосудна.

В Україні установчу функцію регламентовано «Порядком здійснення заходів, пов'язаних з утворенням, реорганізацією або ліквідацією міністерств, інших центральних органів виконавчої влади», затвердженим постановою Кабінету Міністрів України від 20 жовтня 2011 р. № 1074 з подальшими змінами [14].

У зазначеному нормативному акті (п.п. 2 п. 1) наголошується на тому, що «дія цього Порядку поширюється на центральні органи виконавчої влади із спеціальним статусом та їхні територіальні органи, крім випадків, коли Конституцією та законами України визначені особливості порядку їхнього утворення, реорганізації або ліквідації.

Органи виконавчої влади утворюються, реорганізуються або ліквідуються Кабінетом міністрів України за поданням Прем'єр-міністра України. Пропозиція щодо утворення, реорганізації або ліквідації органу виконавчої влади вноситься Прем’єр-міністрові України членом Кабінету Міністрів України з урахуванням пріоритетів діяльності Кабінету Міністрів України, необхідності забезпечення здійснення повноважень органів виконавчої влади й недопущення дублювання їхніх повноважень» [14].

Згідно з Конституцією державна влада в Україні поділяється на три гілки виконавчу, законодавчу та судову, аналогічно можна поділити й державний контроль на парламентський, урядовий (адміністративний) і судовий контроль. Окремо можна виокремити також президентський контроль та прокурорський нагляд.

Президент України є найвищою посадовою особою держави та гарантом дотримання державного суверенітету, територіальної цілісності України, Конституції України, прав і свобод людини й громадянина. Крім того, Президент України щорічно видає значну кількість указів, розпоряджень та доручень, які $\epsilon$ невід'ємною частиною правової діяльності держави й обов'язкові для вико- 
нання на території України. Відповідно найвищим проявом президентського контролю $\epsilon$ контроль за дотриманням вимог Основного Закону України всіма суб'єктами суспільно-правових відносин: громадянами та їхніми об'єднаннями, недержавними установами, органами місцевого самоврядування й органами державної влади та управління [5].

Президент свої контрольні повноваження здійснює безпосередньо або через Офіс Президента України, у складі якого реалізацією контрольної функції нині займається Департамент документального забезпечення. Опосередкований президентський контроль 3 урахуванням вертикального положення, яке займають окремі суб'єкти, здійснюється відповідними органами виконавчої влади згідно з вимогами чинного законодавства [5].

Основними формами парламентського контролю є: проведення Днів Уряду України, проведення парламентських слухань, заслуховування чергових і позачергових звітів Кабінету Міністрів України про його роботу загалом чи 3 окремих питань діяльності, реалізація народними депутатами України свого права на депутатський запит та депутатське звернення, діяльність Рахункової палати, інституту Уповноваженого Верховної Ради України з прав людини [5].

Для забезпечення реалізації прийнятих Верховною Радою України актів, які виражені у формі законів, постанов, резолюцій, звернень та ін. - 18 вересня 2020 р. було зареєстровано законопроєкт № 4131, у якому закріплені положення що дадуть змогу підвищити ефективність системи парламентського контролю в Україні. У законопроєкті передбачено певну змістовність та наповненість звітів, які подаються до Верховної Ради України, що перетворює надання інформації парламенту формі звітів на реальний парламентський контроль. Таким чином отримана Верховною Радою інформація порівняно з минулими роками дає змогу робити висновки про результати та ефективність роботи не тільки окремих державних органів, а й конкретних посадових осіб [17].

У законопроєкті передбачено «встановлення вимог до звіту про діяльність прокуратури, який Генеральний прокурор подає Верховній Раді України. Законопроєкт також передбачає, що програма діяльності Кабінету Міністрів України повинна містити програмні цілі, критерії досягнення програмних цілей та завдання, виконання яких $є$ необхідним для досягнення цілей. Крім того, законопроєктом пропонується включити до щорічної доповіді Уповноваженого Верховної Ради України з прав людини питання виконання рекомендацій, що містились у щорічній доповіді за попередній рік» [17].

Підвищення дієвості здійснюваних Верховною Радою України контрольних повноважень, звісно, спонукатиме до більш результативної діяльності як самого Уряду, так і всіх інших органів, що входять до системи органів виконавчої влади, та є підзвітними й підконтрольними урядові. А за цим, у свою чергу, ми розуміємо що значно підвищується і дотримання прав і свобод людини й 
громадянина з боку владних структур. Відтак, на наш погляд, посилюється контроль за безпосереднім утіленням у життя, тобто безпосередньою реалізацією прийнятих Верховною Радою законів.

У Висновку № 1-в/2001 від 14 березня 2001 р. Конституційний Суд України зауважує: «Парламентський контроль є формою реалізації громадянами опосередковано їхніх конституційних прав, зокрема на здійснення влади через органи державної влади (ст. 5), на участь в управлінні державними справами (ст. 38), на здійснення свого волевиявлення через вибори (ст. 69 Конституції України)» [15]. Отже, парламентський контроль відіграє значущу роль у побудові України як демократичної, соціальної правової держави.

Відповідно до Закону України «Про Кабінет Міністрів України» від 27 лютого 2014 р. № 94-VII «Кабінет Міністрів України здійснює виконавчу владу безпосередньо та через міністерства, інші центральні органи виконавчої влади, Раду міністрів Автономної Республіки Крим та місцеві державні адміністрації, спрямовує, координує та контролює діяльність цих органів [16].

Урядовий (управлінський) контроль безпосередньо здійснюють Управління контролю Секретаріату Кабінету Міністрів України, підрозділи з контролю відповідних міністерств та інших центральних органів виконавчої влади, департаменти або відділи контролю на місцевому рівні, статус яких визначено відповідно постановою Кабінету Міністрів України від 26 грудня 2003 р. № 2037 та постановою Кабінету Міністрів України від 21 серпня 2000 р. № 1290 із змінами й доповненнями.

Чільне місце в системі контролю за органами державного влади відведене контролю, який здійснюють суди і це є суто важливим на сучасному етапі розбудови української державності. Конституція України містить положення щодо правового захисту від неправомірних дій або бездіяльності державних органів, що надалі втілюються в нормах «Кодексу адміністративного судочинства України» від 06 липня 2005 р. № 2747-IV та в інших нормативноправових актах. Відтак, громадяни мають право на звернення про захист свого порушеного права до судів загальної юрисдикції, спеціалізованих судів на всіх рівнях судової влади та до Європейського Суду з прав людини.

У разі відмови від добровільного виконання рішення суду в Україні створені й діють органи державної виконавчої служби, які здійснюють примусове їхнє виконання згідно із законодавством України, та крім органів державної виконавчої служби чинним $є$ інститут приватних виконавців: «завданням державної виконавчої служби та приватних виконавців $є$ вчасне, повне й неупереджене виконання рішень, примусове виконання яких передбачено законом» [18]. Органам прокуратури також відведено важливе місце в системі здійснення державою контрольних функцій. Стаття 2, ч. 1, п. 4 Закону України «Про прокуратуру» надає прокуратурі повноваження 3 «нагляду за додер- 
жанням законів під час виконання судових рішень у кримінальних справах, а також у процесі застосування інших заходів примусового характеру, пов'язаних з обмеженням особистої свободи громадян» [19].

Окремою правовою формою діяльності держави - $\epsilon$ правосуддя, що встановлює, змінює та припиняє конкретні правовідносини. Специфіка цих правозастосовних актів полягає в тому, що вони слугують відновленню порушеного права, реалізації юридичної відповідальності особи, яка вчинила правопорушення, а, відтак, у всіх випадках - захисту інтересів громадян i суспільства загалом.

Українська дослідниця Т.В. Дружиніна-Сендецька вважає, що все різноманіття думок науковців і практиків щодо того, чи є інтерпретаційноправові акти судової влади джерелом права, можна систематизувати й об'єднати в три групи [4].

Представники однієї групи дотримуються думки, що судова практика, незалежно від форм іiі вираження, джерелом права бути не може. Друга група вчених висловлює протилежну думку, вважаючи, що судова практика, залежно від результатів діяльності судів, у повному обсязі є джерелом права, а суд творцем права.

Прибічники третьої думки намагаються знайти щось середнє між категоричними твердженнями перших двох груп авторів і вважають, що судова практика - джерело права, але тільки в тій частині, у якій вона відтворюється в актах тлумачення Верховного Суду [4].

Здійснений аналіз юридичної літератури, у якій так чи інакше порушуються проблеми судової нормотворчості, виявив різноманіття підходів авторів до цієї проблеми. Існує думка, що всі рішення судів можна охопити поняттям «правові акти» в широкому значенні. Р.3. Лівшиц висловлюється 3 цього приводу досить обережно, побоюючись однозначно прирівнювати судову практику до норм права, доповнюючи свій погляд застереженнями й умовами [6].

Зокрема, на думку вченого, акти судових органів посідають «своєрідне місце в системі джерел права». До того ж ця своєрідність виявляється в безперечно підпорядкованому характері судових актів, які містять норми права загального характеру щодо конституції та законів. Інші науковці говорять про можливість їхньої належності до підзаконних нормативних актів. Останнім часом значно пожвавилася дискусія про те, що аналіз правової природи судової практики дає підставу зробити висновок про прецедентний характер рішень вищих судових інстанцій. У правовій літературі пропонуються різні класифікації судових прецедентів. Залежно від правового змісту автор розрізняє три види прецедентів: «прецедент тлумачення, прецедент роз'яснення і прецедент, що містить нову норму. Цей класифікаційний критерій висувається через 
необхідність розмежування інформаційної та нормативної новизни в судовому рішенні, що претендує на роль прецеденту» [8].

А.Б. Венгеров вважає, що прецеденти тлумачення правової норми містяться в мотивувальній частині постанов і ухвал найвищих судових інстанцій, винесених щодо конкретних справ. Вони роз'яснюють уже наявну норму права, тому, на відміну від судового прецеденту, у країнах англосаксонської правової сім’ї не ведуть до створення нової норми права, а пов’язуються 3 «виробленням певного сталого положення про застосування норми права в аналогічних справах Суду» [8].

Найчастіше, i до того ж як показує практика країн із прецедентним правом, одного разу прийняте рішення, визначене положення про тлумачення й застосування норми права стає загальновживаним, обов'язково приймається до уваги судами у вирішенні судових справ, «сприяє поліпшенню судової діяльності, а тим більше прецедент тлумачення не зводиться до кожного випадку офіційного казуального тлумачення закону вищою судовою інстанцією країни, що загалом є явищем дуже поширеним. Можливість бути саме «прецедентом», прикладом, зразком і тому додатковим регулятором суспільних відносин йому надають певні ознаки:

1) відповідність змісту норми, що тлумачиться основним принципам права;

2) сприйняття тлумачення судовою практикою, тобто неодноразове подальше використання розуміння закону, що одного разу відбулося, в аналогічних справах;

3) вироблення в акті тлумачення певного положення про пояснення змісту норми й подальшого законного й обгрунтованого іiі застосування;

4) надання прецеденту тлумачення зовнішнього виразу у формі його видання Судом» [8].

Оскільки законодавець не завжди зрозуміло й точно висловлює зміст норми права, що спричиняє непорозуміння, а саме різне тлумачення та неузгодженість зроблених висновків та неоднакове застосування норми, - судове тлумачення дає змогу внести чіткість, точність у смисловий зміст застосовуваної норми.

На основі розглянутих вище поглядів у науковій літературі можна прийняти за основу таке визначення правових форм здійснення функцій державної влади, одну з груп визначень: процесуальні, суб'єктні та інструментальні. Вважаємо за доцільне запропонувати визначення, у якому б комплексно поєднувалися особливості всіх трьох груп. Отже, під правовими формами реалізації функцій державної влади будемо розуміти засоби формалізованого вираження волі гілок влади, органів та посадових осіб апарату держави, які дозволяють здійснювати нормативне регулювання різних напрямів активності держави 
(законодавчої, виконавчої, судової, контрольно-наглядової) щодо реалізації державою певних цілей та завдань у різних сферах управління суспільством (економічній, ідеологічній, військовій, культурній тощо).

Проголошення України соціальною державою вимагало не лише формального самовизначення ï соціальної спрямованості, але й розроблення стратегії соціальної політики держави як основного напряму діяльності такої держави.

Діяльність соціальної держави базується на загальноправових та спеціально законодавчих принципах. Перша група принципів - загальноправові визначають основу діяльності держави не лише в соціальній сфері, але й в інших напрямах іiі діяльності. Друга група принципів - спеціально законодавчі - визначають засади формування нормативних актів соціального законодавства.

3 огляду на реальну ситуацію, що склалася в нашій державі із соціальним захистом населення, доцільно виокремити такі два принципи соціальної діяльності української держави: принцип доступності, який передбачає спрощення законодавства для більш ефективного його використання широким колом осіб, та принцип забезпечення мінімальних доходів населення - забезпечення гарантованих державою мінімальних доходів громадян.

Правові форми реалізації соціальної функції української держави пов’язані з прийняттям нормативних актів, що регулюють соціальні відносини щодо забезпечення соціального захисту, соціального перерозподілу та соціальної безпеки в суспільстві. Нормативні акти, що регулюють соціальні відносини, можуть прийматися органами законодавчої та виконавчої влади, а також органами місцевого самоврядування.

Оскільки в процесі правозастосування можуть виникати різночитання щодо тлумачення тих чи інших норм соціального законодавства з боку різних зацікавлених суб'єктів, і це спричинятиме суперечки в інтерпретаціях, то в процес виконання державою іiі соціальної функції можуть залучатися суди загальної та спеціальної юрисдикції та Конституційний Суд України.

Висновки. Форми здійснення функцій держави є зовнішнім вираженням діяльності держави в тому чи іншому напрямі. Вони бувають правовими й неправовими. Сутність правових форм здійснення функцій держави полягає в однорідній за своїми зовнішніми ознаками (спрямованістю та юридичними наслідками) діяльності державних органів, пов'язаної з виданням нормативних актів.

3 огляду на це правовими формами реалізації функцій держави в теорії держави й права прийнято вважати правотворчу та правозастосовну діяльність, яка зі свого боку поділяється на оперативно-виконавчу та правоохоронну. Отже, на нашу думку, соціальна функція української держави може реалізовуватися в 
правотворчій, правовиконавчій (екзекутивній) та правоінтерпретаційній формах. Зокрема правоінтерпретаційна форма реалізації передбачає деякі обставини порушення соціальних прав та свобод різних суб'єктів і необхідність їхнього звернення до судових органів із клопотаннями щодо роз'яснення змісту статей відповідних нормативних актів та надання їхнього офіційного тлумачення.

\section{Література}

1. Шай Р.Я. Правоохоронна функція правової держави: теоретико-практичні аспекти: автореф. дис. канд. юрид. наук. Львів, 2012. 20 с.; 2. Сырых В.М. Теория государства и права: учебник. 6-е изд. М.: Юстицинформ, 2012. 704 c. URL: https://e.lanbook.com/book/ 10684; 3. Мельничук С.М. Правоохоронно-правозастосовна діяльність здійснення функцій держави: проблеми сучасного розуміння. Інформація $і$ право. 2015. Вип. 2(14). С. 42; 4. Дружиніна-Сендецька Т.В. Тлумачення у праві: особливості герменевтичного підходу: автореф. дис. канд. юрид. наук: 12.00.01 / Нац. юрид. академія України ім. Ярослава Мудрого. Харків, 2015. 16 с.; 5. Конституція України: прийнята 28 червня 1996 р. // Відом. Верховної Ради України. 1996. № 30. URL: https://zakon.rada.gov.ua/laws/show; 6. Лившиц Р.3. Государство и право в современном обществе // Теория права: новые идеи. М.: Наука, 1991. Вып. 1. С. 66-101; 7. Теорія держави і права. Академічний курс: підручник / за ред. О.В. Зайчука, Н.М. Оніщенко. 2-е вид., перероб. і допов. Київ: Юрінком Інтер, 2008. 688 с.; 8. Венгеров А.Б. Теория государства и права: учебник. Москва: Дашков и К, 2019. 608 с. URL: http://www.iprbookshop.ru/85459.html.; 9. Чиркин В.Е. Государственное управление: элементарный курс. Москва: Юристь, 2001. 318 с.; 10. Теория права и государства: учебник для юрид. вузов / В.С. Афанасьев и др.; под ред. В.В. Лазарева. Москва: Право и закон, 1996. 424 с.; 11. Черданцев А.Ф. Теория государства и права: учебник для вузов. Москва: Юрайт, 2000. 123 с.; 12. Цвік М.В., Петришин О.В. Загальна теорія держави і права: підручник. Харків: Право, 2010. 13. Рішення Конституційного Суду України у справі № 1-36/2010 від 10 червня 2010 p. URL: https://zakon.rada.gov.ua/laws/show/v001v710-01\#Text; 14. Постанова Кабінету міністрів України від 20 жовтня 2011 р. «Про затвердження порядку здійснення заходів, пов'язаних з утворенням, реорганізацією або ліквідацією міністерств, інших центральних органів виконавчої влади». URL: https://zakon.rada.gov.ua/laws/show/794-18\#Text; 15. Висновок Конституційного Суду України у справі за зверненням Верховної Ради України про надання висновку щодо відповідності проекту Закону України «Про внесення змін до Конституції України (статей 84, 85, 89, 92, 93, 94, 106, 147, 150, 151 та пункту 6 розділу XV Конституції України)» вимогам статей 157 і 158 Конституції України (справа про внесення змін до статей 84, 85 та інших Конституції України). URL: https://zakon.rada.gov.ua/laws/ show/v001v710-01\#Text; 16. Закон України від 27 лютого 2014 р. «Про Кабінет Міністрів України» № 94-VII. URL: https://zakon.rada.gov.ua/laws/show/794-18\#Text; 17. Проект Закону про внесення змін до деяких законів України щодо забезпечення ефективної реалізації парламентського контролю № 4131 від 18.09.2020. - URL: http://w1.c1.rada.gov.ua/pls/zweb2/ webproc4_1?pf3511=69998; 18. Закон України «Про органи та осіб, які здійснюють примусове виконання судових рішень і рішень інших органів» від 2 червня 2016 р. № 1403-VIII // Відомості Верховної Ради (ВВР). 2016. № 29, ст. 535; 19. Закон України «Про прокуратуру» від 14 жовтня 2014 р. № 1697-VII // Відомості Верховної Ради (ВВР). 2015. № 2-3, ст. 12. 